\title{
Assessment Of Psychological Advertising Along Consumer Rights And The Rule On Section 5 Of The Federal Trade Commission, Part 1 Of 2: Unfairness Doctrine
}

\author{
Michelle Alarcon, Hawaii Pacific University, USA
} Joseph Ha, Hawaii Pacific University, USA

\begin{abstract}
Over a century of research and empirical findings have linked advertising with consumer choice based on affective information processing, which many researchers emphasized as unconscious brain processing. This paper examines a variety of empirical findings and historical data on psychological or affective processing which provides evidence that psychological advertising affects consumer behavior and choice. Thereafter, building on existing research and literature, we analyze the legal implications of psychological advertising to stimulate affective or unconscious decisions that impairs rational choice and thus harmful. Based on this argument, we analyze the current federal consumer protection law regulating advertising under Section 5 of the Federal Trade Commission Act ("FTC Act”) which bans unfair and deceptive practices, then present rationales for change followed by a framework for revision. The objectives of such change is to ensure that this regulation upholds consumer rights and provide a consumercentric process that respects free choice. One outcome of this proposal will be a ban on advertising practices that utilize psychological stimuli. The framework will focus on expanding the "unfairness" doctrine of the FTC Act. The Federal Trade Commission ("FTC") states that "unfair acts or practices injure both consumers and competitors because consumers who would otherwise have selected a competitor's product are wrongly diverted by the unfair act or practice," thus an effective customer-centric regulation could postulate a healthier economy.
\end{abstract}

Keywords: Sec 5 Of The FTC; Psychological Advertising; Unfairness Doctrine; Unfair and Deceptive Practices

\section{INTRODUCTION}

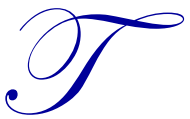

his paper is organized as follows. Section 1 discusses psychological advertising and outlines how psychology in advertising influences consumer behavior and decision based on published research that spans over a century of this knowledge. In Section 2, we outline some historical research data on how psychology in advertising influences consumer behavior and decisions which provides evidence for our legal proposal to ban psychological advertising practices. Section 3 discusses the legal implications of psychological advertising by analyzing Consumer Rights that provides the basis for consumer protection and the federal law under Sec 5 of the FTC Act regulating advertising and its application to psychological advertising. Section 4 presents the primary author's proposed framework for legal change in interpreting the unfairness criteria to regulate psychological advertising. Section 5 introduces an abstract of the discussion on the deceptive criteria of the FTC Act and invites further research on the economic implications of this type of advertising practice and its effects on competition.

This paper theorizes that the use of any form of psychological conditioning, science, or knowledge in advertising, especially the affective kind, deprives consumers of their inalienable right to information and choice as psychological manipulation tricks the mind in making irrational decisions based on emotions and other sensory perceptions. Rational decision making forces the mind to objectively assess the qualities and features of the product or service while 
affective decision making forces the mind to subsume or totally ignore these objective qualities and use emotions or other perceptions to make decisions. Therefore, this trend would drive competition based on whoever has the deep pockets to pay for research on psychology to produce ads that are most effective in influencing the mind and launching such ads in massive doses, rather than competition based on the traditional notions of marketing based on product differentiation and/or superiority. On its face, it is clear that such manipulative practices are "immoral, unethical, oppressive, or unscrupulous" (Belt quoting the Federal Trade Commission (FTC)'s former interpretation of "unfairness".)

\section{HOW PSYCHOLOGY IN ADVERTISING INFLUENCES CONSUMER BEHAVIOR AND DECISION}

Advertising started as word of mouth with "the merchant who had wares to offer brought them to the gate of a city and there cried aloud, making the worth of his goods known to those who were entering the city, and who might be induced to turn aside and purchase them." (Scott, 1902). The primary purpose of advertising back then, and how it should be now, is to make the worth of goods "known." Anything beyond giving knowledge or material information to consumers must pass nothing less than strict scrutiny. This includes advertising practices and strategies that utilize any and all forms of psychological and/or affective conditioning devoid of basic, special, and/or and material information about the advertised items, inducing sales through mind techniques rather than product differentiation, superiority, or other material aspects necessary for an informed decision. The field of marketing notes that the purpose of advertising is to inform, persuade, and identify (Nickels, 2013). Advertising is further defined as "...paid, nonpersonal communication through various media by organizations and individuals who are in some way identified in the message." (Nickels, 2013)

Advertising has evolved into one of the most important aspect of business and the economy quickly emerging in all media discovered or invented in every era (Nickels, 2013). "The impact of advertising spending on the U.S. economy reached a total ad volume exceeding $\$ 241$ billion yearly from different media including direct mail, broadcast TV, newspaper, cable TV, radio, yellow pages, consumer magazine, internet, and others." (p. 439). With such distribution platform, advertising has engulfed people's lives in almost every visible space. As such, the content and delivery of advertising must be scrutinized to ensure that consumers are not exploited to the detriment of society as a whole. This calls for an absolute respect for consumer rights and other public policies.

Research in advertising, consumer behavior, and psychology has consistently shown that the marriage of psychology and advertising has shifted the role and function of advertising from provider of information to a big psychological machine. The application of psychology in advertising has reached a level of sophistication that businesses invest billions of dollars each year to produce highly sophisticated advertisements, most of which apply psychological techniques to manipulate consumer behavior. These funds could have been diverted to product development if businesses do not see a lucrative return of investment. The use of psychological appeal or affective advertising has risen to enormous proportion in a span of over a century. This warrants a deeper analysis on how this practice violates consumer rights, particularly the right to choose freely and the right to information which stems from the Consumer Bill of Rights introduced by the U.S. President, John F. Kennedy in 1962. Further actions to cease such unfair and deceptive practices that exploit consumers. These are inalienable rights that deserve the highest treatment of respect and adherence by law and society. Adverting's goal of informing, persuading, and reminding must strictly and clearly align with these consumer rights. However, with the marriage of psychology and advertising, the goal of information delivery has eroded, and the persuasion function has evolved to psychological manipulation on a scientific level.

What is Affective and/or Psychological Conditioning? Affect is a term often used in consumer research and $\mathrm{r}$ affective states covers both emotion and feelings (Damasio, 2003) and is thus a less specific concept. "In psychology, conditioning is a form of learning in which a response is elicited by a neutral stimulus which previously had been repeatedly presented in conjunction with the stimulus that originally elicited the response." (Medical Dictionary, n.d.)

This section provides a small sample of the massive evidence that could be gathered from scholarly research, journal articles, court cases, and other materials dating as far back as 1895 to show 1.) the effects of psychology in advertising; 2.) that psychology is intentionally utilized in advertising practices; and 3.) that advertisers use this practice to influence consumer behavior and decision making: 
1895 - Beginning of the marriage of psychology and advertising: Research on the subject of psychology in advertising dates back over a century ago in 1895 when Harlow Gale surveyed Minnesota business to study how people process ads.

1902 - Prediction for the future and encouragement on the use of psychological advertising: In 1902, Walter Dill Scott, Assistant Professor of Psychology in Northwestern University, published "The Psychology of Advertising in Theory and Practice: A simple exposition of the principles of psychology in their relation to successful advertising" where he encourages the use of psychological advertising: (see Appendix 1A)

Advertiser's goal to influence the human mind: In 1903, Scott published "The Theory and Practice of Advertising" where he was credited for giving scientific credibility to psychology in advertising where he argued that people are highly suggestible and obedient (Todd, 2011). In 1904, Scott wrote a series of studies of Modern Advertising. Some of his statements declare the impact of psychology in advertising to consumer behavior. (see Appendix 1B)

Pricing tricks to influence the mind: "The psychology of pricing explains why we do many of the silly things we do with our money. Retailers work hard to manipulate us, tweaking price tags and offering "special" promotions to get us to spend more than we normally would" (Torabi, 2011). Torabi interviewed a couple of behavioral science and marketing experts and reviewed some academic studies to round up the most popular pricing tricks (see Appendix 1C):

Appeal to basic emotions: John B. Watson, former chair at Johns Hopkins University, was a highly recognized psychologist in the 1920's who implemented the concept of behaviorism into advertising which focuses on appealing to the basic emotions of the consumer on love, hate, and fear as a direct command to the consumer.

Ways to influence behavior: Scott writes about the benefit of awakening the feelings and emotions and suggested the following strategies as effective ways in bringing about desired action: appeal to customer's sympathy (Scott, 1902): 143 , appealing to the esthetic sense; four principles for impressing advertisements on the minds of possible customers are capable of unlimited application, and will not disappoint any; for they are the laws which have been found to govern the minds of all persons as far as their memories are concerned (Scott, 1902):122 - 1. Repetition - The advertisement that is repeated over and over again at frequent intervals gradually becomes fixed in the memory of the reader (Scott, 1902):115; 2. Intensity; 3. Association - advertisement should be such as are easily associated with the personal interests and with the former experience of the majority of the readers; and 4. Ingenuity (Scott, 1902)

Effects of emotional appeals in advertising: Taute, H.A., et al., (2011) write that "there is evidence that people process emotional information when they view persuasive appeals and, to some degree, use such information to form attitudes and behavioral intentions.... research suggests that creating advertising messages that generate positive affective states is more beneficial for influencing the attitudes and behaviors of people who possess high EIM (Emotional Information Management) skills." (Taute, H.A., et al., 2011). Impulse purchases arise out of an immediate and intense emotional attachment or personal identification with the product (Rook 1985). Taute, H.A., et al., (2011) quote several published authors with research on the strength of emotional appeals in advertising and reliance on classical conditioning. (see Appendix 1D)

Advertisement create needs, not fulfill them: Trampe's (2010) research states that advertised products can affect how consumers think about themselves and that "even simple advertisements that display the product and a brand name may trigger thoughts about one's own shortcomings. This supports Pollay's statement that modern advertising seeks to create needs, not to fulfill them" (quoting Pollay, 1986, p. 26).

Emotional appeals that could impair self-control and influence immediate decisions - Bulbul, (2010), helps extend our thinking on the role of emotional appeals in advertising as they introduce a new distinction in such appeals: "concrete versus abstract affect" (see Appendix 1E).

Consumers can make judgments based largely on emotions. (see Appendix 1F)

Advertising works on unconscious awareness: (see Appendix 1G)

Copyright by author(s); $\underline{\text { CC-BY }}$ 
Brand associations can unknowingly drive us to choose: (see Appendix 1H)

Advertising influences consumers on a subconscious level: (see Appendix 2)

EEG (Electroencephalography) science was applied to advertising to learn about attention in consumers: (see Appendix 1J)

Neuromarketing is a new technology currently used to understand better how to boost effectiveness of advertising: this is a new field that allows businesses to literally read your mind to determine why you choose some products over others your choice of products and companies like Facebook, McDonald's, Disney, Citigroup, and Unilever already use this technology. Consumer activists warns that "it is having an effect on individuals that individuals are not informed about." (Lawrence, 2014)

\section{THE LEGAL IMPLICATIONS OF PSYCHOLOGICAL ADVERTISING: TYING CONSUMER RIGHTS TO SEC 5 FTC}

\section{Consumer Rights}

Building on over a century of research that psychological advertising influences consumer behavior and decision making choice, this paper contends that such practices strikes at the heart of consumer rights decreed by President John F. Kennedy in his speech on March 15, 1962 which promises to give high priority on consumer protection. This was a special message to congress on protecting the consumer interest, which we now call JFK's Four Consumer Rights (Lampman, 1997). The first four rights defined and limited the field of consumer protection, which includes:

1. The right to safety--to be protected against the marketing of goods which are hazardous to health or life.

2. The right to be informed--to be protected against fraudulent, deceitful, or grossly misleading information, advertising, labeling, or other practices, and to be given the facts he needs to make an informed choice.

3. The right to choose--to be assured, wherever possible, access to a variety of products and services at competitive prices; and in those industries in which competition is not workable and Government regulation is substituted, an assurance of satisfactory quality and service at fair prices.

4. The right to be heard--to be assured that consumer interests will receive full and sympathetic consideration in the formulation of Government policy, and fair and expeditious treatment in its administrative tribunals." Kennedy (1962), (Lampman, 1997)

Since this proclamation, several consumer protection laws had emerged or existing ones enhanced. Further, the set of rights has since expanded to eight to include the right to privacy, the right to redress, the right to consumer education, and the right to a healthy environment.

Chang states that a body of evidence suggests that people possess two modes of judgment and decision making: a reason-based, analytical system and a feeling-based, affective system (Chang, Pham, 2012, quoting Pham 1998.) Research demonstrates that the feeling-based, affective system is used in psychological advertising practices to influence consumer behavior and decision without them assessing, weighing, and combining attribute information into an overall evaluative judgment. This type of practice transgresses at least two of the four original consumer bill of rights, namely the right to be informed and the right to choose discussed below.

Right to be informed contains two requirements on businesses: first, not to engage in fraudulent, deceitful, or grossly misleading information, advertising, labeling, or other practices; and second, that consumers be given the facts he needs to make an informed choice. (Lampman, 1997). Affective advertising or any form of psychological manipulation may be deceitful of grossly misleading, such as those that use artifacts in their message to insinuate social status. Examples are ads with false-dichotomies where an option is given, e.g., buy the advertised product or be a socially inept; buy or be alone. The question is not simply about truth of the premises, but rather on the validity of the conclusion from those premises. (Persuasion, Manipulation, and Responsibility, n.d.). For the second requirement, one can find that the media is plaque with advertisements that do not contain facts and objective information about the item but uses artifacts or screenplay that play on emotions. They contain very minimal information about the 
product but focus the audience on the brand or image along an emotional trigger. Examples include those mentioned on section 2 of this paper. The misleading information in this type of practice is to make the viewer believe that the advertised item will either satisfy their emotional need or that they can experience the same emotional satisfaction or result as the characters or situation in the ad. Another form of deception or grossly misleading information are advertising practices that otherwise create needs that may not have existed in a consumer's reality but cleverly concocted through affective conditioning. (Pollay, 1986, p. 26) (Trampe, 2010)

Right to choose assures access to goods and services. We believe that psychological manipulation controls consumer's choice and violates this right in ancillary manner as "manipulation includes any deliberate attempt by a person P to elicit a response desired by $\mathrm{P}$ from another person $\mathrm{Q}$ by noncoercively altering the structure of actual choices available to Q or by nonpersuasively altering Q's perceptions of those choices [i.e. without rational persuasion]" (Beauchamp, 1983)

These consumer rights are clearly defined and it is clear that the type of advertising that respects these rights are those that serve its original functions of information, persuasion, and identification (Nickels, 2013). Information must be objectively based on facts that differentiate the item from its competitors, including statements about product/service superiority or uniqueness. Persuasion must be based on this information and conducted in a manner that respects human dignity and intelligence to allow rational decision making without any element of psychological control. Researchers suggests that if an advertiser was coercing people into purchasing products or services, one would consider the advertiser quite responsible for the activity. The basic principle one can see from this is that less rational persuasion seems to entail less responsibility on the part of the consumer (Persuasion, Manipulation, and Responsibility, n.d.).

\section{Sec 5 of the Federal Trade Commission Act (also referred herein as "Act" of "FTC Act") - What Sector Is This Law Trying to Protect? Consumers or Businesses?}

Advertising practices that have been within reach of the law are those involving express statements or claims about the advertised items. In section 2 supra, we discuss how psychological advertising practices influence consumer behavior and decision making, apply brain science to trick the mind. As consumer activists warns, this practice is affecting consumers in ways they are not informed about. A strict rule would be to ban psychological advertising as deception per se in violation the FTC Act and other related consumer protection laws. As an alternative, rules must regulate the application of psychological science or schemes as an unfair practice within the meaning of the law.

Consumer protection laws are linked to the idea of consumer rights and are government regulations designed to prevent businesses from deceptive or unfair practices. Organizations that promote consumer protection include government organizations and self-regulating business organizations such as consumer protection agencies and organizations, the FTC, ombudsmen, Better Business Bureaus, etc.

Of the group of laws, Sec 5 of the FTC Act directly governs advertising practices in the United States, and codified by (15 U.S.C. $\S \S 41-58$, as amended). The FTC's mission is to prevent business practices that are anticompetitive or deceptive or unfair to consumers; to enhance informed consumer choice and public understanding of the competitive process; and to accomplish this without unduly burdening legitimate business activity. (FTC.gov, n.d.) This paper, however, challenges the part of this FTC's mission that conditions protection of consumers on how such protection would "unduly burden legitimate business activity." This mission statement places business activities above consumer protection by imposing such a condition. See Figure 1: FTC Mission Statement and Consumer Rights. 
Figure 1. FTC Mission Statement and Consumer Rights
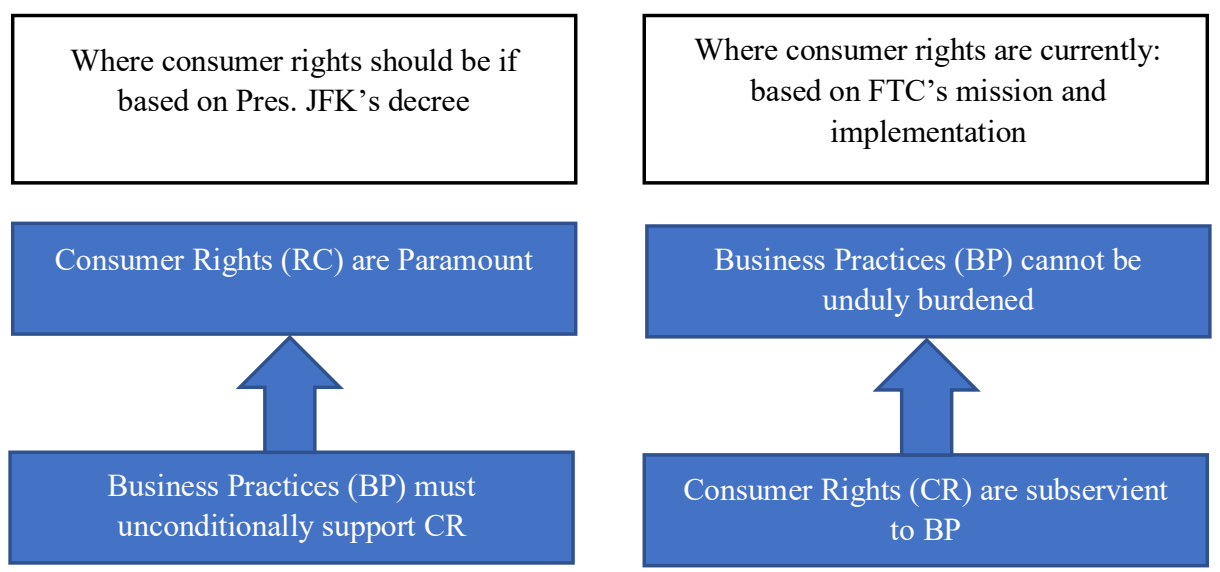

This FTC mission is important to note as this explains the overarching direction of the implementation of this consumer regulation. Following the trend of erosion of the spirit of consumer protection, The National Consumer Law Center released its 2009 report on the 50-State Unfair and Deceptive Acts and Practices Statutes (UDAP) with a finding that in almost all states significant gaps and weakness undermine the protection of the state unfair and deceptive acts and statutes. Further emphasizing that " $[t]$ he holes are glaring. Legislation or court decisions in dozens of states have narrowed the scope of UDAP laws or granted sweeping exemptions to entire industries. Other states have placed substantial legal obstacles in the path of officials charged with UDAP enforcement, or imposed ceilings as low as $\$ 1,000$ on civil penalties. And several states have stacked the financial deck against consumers who go to court to enforce the law themselves." (Carter, 2009). See Appendix 2.

Sec 5 FTC provides that "unfair or deceptive acts or practices in or affecting commerce...are...declared unlawful." (15 U.S.C. Sec. 45(a)(1)) Safe Web amended Sec. 5(a) to include such acts or practices involving foreign commerce that cause or are likely to cause reasonably foreseeable injury within the United States or involve material conduct occurring within the United States. (Federal Trade Commission, 2008) Section 12 specifically prohibits false ads likely to induce the purchase of food, drugs, devices or cosmetics. Section 15 defines a false ad for purposes of Section 12 as one which is "misleading in a material respect." (FTC Policy Statement on Deception, 1983)

The legal standard for unfairness is independent of the legal standard for deception. Depending on the facts, an act or practice may be unfair, deceptive, both, or neither. (FDIC Compliance Manual Vol. VII, 2014) This paper will focus on the unfairness doctrine and assess its application to advertising practices that apply psychological techniques.

\section{Unfairness Doctrine and Psychological Advertising}

The FTC Act requires that consumer injury must meet three tests before an act or practice is deemed unfair:

1. That the injury be substantial;

2. That the injury must not be outweighed by any countervailing benefits to consumers or competition that the practice produces; and

3. That the injury must be one that consumers themselves could not reasonably have avoided. The FTC further notes that it will not find that a practice unfairly injures consumers unless it is injurious in its net effects." (Belt, 2010). 
Figure 2. Consumer's Burden of Proof to Establish Whether an Act is Unfair under Sec 5 FTC
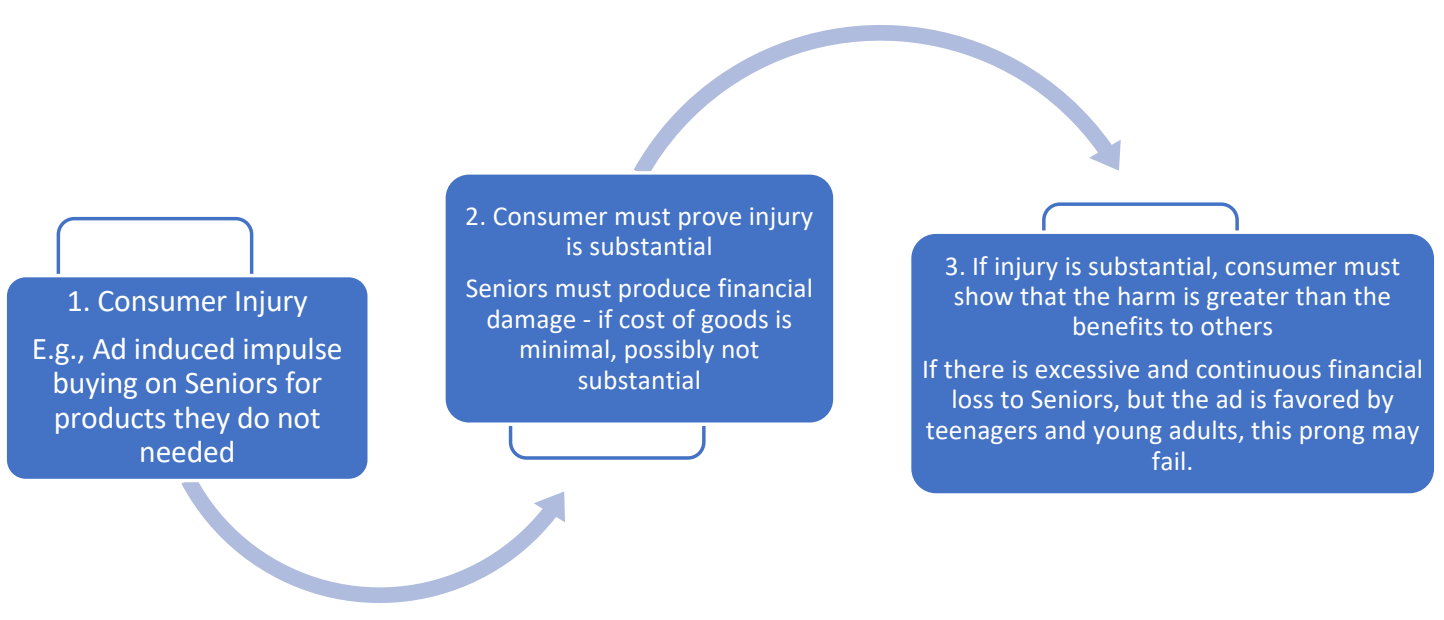

Former FTC Director J. Howard Beales noted that this is an important and useful tool to address difficult problems and improve consumer protection in areas that the deception criteria does not fit but nevertheless causes substantial injury to consumers. (Beales, 2003). However, further analysis of the three prongs shows that the burden on consumer to demonstrate unfairness is too heavy such that he spirit of the law in upholding consumer rights is eroded. The current interpretation provides legal loopholes that allow many immoral, unscrupulous, unethical, and oppressive business practices that hurt consumers to escape the law and propagate in massive scale, e.g., ads directed to children and psychological advertising. This calls for an analysis as to which sector of society is this law protects the most AND whether the law upholds consumer rights. It is vital to follow the history of the interpretation of the unfairness doctrine. Following its history, one can see how political and other pressures has shifted the focus of its essence from protecting consumer rights to a more favorable treatment of businesses. The criteria for determining unfairness under the FTC Act has gone through several interpretations and has been a subject of controversy in the FTC and the courts (Belt, 2010). Below are key historical milestones that show how the FTC's interpretation of unfairness evolved to its present form: (see Chart 1 Summary of the Interpretation of the Unfairness Doctrine)

1938: The FTC Act was amended in 1938 to extend the protection of the Act to consumers without the necessity of proving injury to competition or competitors. (Belt, 2010)

1964: In 1964, the "Cigarette Rule" was developed to determine unfairness in connection with the FTC's rule governing the advertising and sale of cigarettes. The factors are: 1) whether the practice offends public policy as set forth in statutes, the common law, or otherwise-whether, in other words, it is in at least the penumbra of some common law, statutory, or other established concept of unfairness; 2) whether it is immoral, unethical, oppressive, or unscrupulous; 3 ) whether it causes substantial injury to consumers (or competitors or other businessmen). (Beales, 2003) Beales noted that from 1964 to 1972, the FTC rarely used the unfairness policy due to hostile reaction from Congress.

1970s: Educational activists demanded noncommercial television and educational programming for young children because consumers began to catch on to the ad agencies psychological techniques. (Psychological Tactics and Appeals in Advertising, n.d.)

1972: In 1972, the Supreme Court reversed the FTC's decision in FTC v. Sperry \& Hutchinson Co. (405 U.S. 233 , $244 n .5$ (1972) and suggested that the 3-prong test can be applied disjunctively. In other words, acts and practices can be unfair if they offend public policy, or, were immoral, etcetera, $\boldsymbol{o r}$ caused substantial injury to consumers.

1978: In 1978, the FTC stated that a practice may be unfair because of the degree to which it meets one of the Cigarette Rule criteria or because to a lesser extent it meets all three. In this year, the FTC proposed a rule to ban advertising directed to children based on the grounds that it was "immoral, unscrupulous, and unethical" and 
against generalized public policies to protect children (Belt, 2010). This proposal became "one of Washington's most controversial regulatory battles of recent years....as the commission has held hearings around the country producing thousands of pages of testimony, Congress has shown its displeasure with the proceeding, and the regulatory mood of Congress and the executive branch has shifted against Government mandating of such issues." (Sulzberger, 1981). The proposal calls for a (1) ban all television advertising for any product which is directed to very young children, (2) ban advertising directed to older children for sugared products which pose serious dental health risks, and (3) require that advertisements directed to older children for other sugared products be balanced by nutritional and/or health disclosures funded by advertisers. Beales wrote that this proposal was " $[\mathrm{t}]$ he most prominent example of overreaching under broad, unfocused, policy-based unfairness also led directly to the downfall of unfairness as a working legal doctrine.” (Beales, 2003)

1980: In June 13, 1980, following the 1978 proposal to ban ads directed to children, Congress threatened the authority of the FTC as to whether the FTC authority should be limited to regulating false or deceptive commercial advertising. Beale writes that "at one point, Congress refused to provide the necessary funding, and simply shut down the FTC for several days. Entire industries sought exemption from FTC jurisdiction, fortunately without success. Eventually, Congress acted to restrict the FTC's authority, including legislation preventing the FTC from using unfairness in new rulemakings to restrict advertising. So great were the concerns that Congress did not reauthorize the FTC for fourteen years. Thus chastened, the Commission abandoned most of its rulemaking initiatives, and began to re-examine unfairness to develop a focused, injury-based test to evaluate practices that were allegedly unfair." The FTC responded with its Unfairness Policy Statement adopting the Cigarette Rule but made three significant differences: (1) it limited the use of the public policy criterion to public policies that were "clear and well-established"; (2) it deleted the second criteria - whether an act or practice was "immoral, unethical, oppressive, or unscrupulous" and justifies this by stating that it has never used "immoral, etc." as an independent basis for finding unfairness (Belt, 2010); and (3) it elaborated on the sub - stantial injury criterion and justifies this by declaring that the unjustified consumer injury criterion was the primary focus of the FTC Act, and the most important of the Cigarette Rule criteria. (Belt, 2010). Belt noted that one of the apparent purposes of adopting the 1980 Unfairness Policy Statement and enacting 15 U.S.C. $\S 45(n)$ was to restrict the FTC's use of its power to regulate unfair practices and that it seems likely that these new criteria would increase the difficulty of establishing a violation. (Belt, 2010)

1981: In 1981, the FTC conceded and ended its 3 years of battle by dropping its investigation into advertising directed to children without suggesting alternatives to a full ban such as disclosures. (Sulzberger, 1981)

1982: In 1982, Congress codified the definition of unfair in 15 U.S.C. $\S 45(n)$, declaring an act or practice as unfair when it causes or is likely to cause substantial injury to consumers which is not reasonably avoidable by consumers themselves and not outweighed by countervailing benefits to consumers or to competition.

1994: In 1994, the rule states that the FTC may consider established public policies as evidence to be considered with all other evidence, but that "[s]uch public policy considerations may not serve as a primary basis for such determinations. This removed the FTC's ability to rely on public policy as a primary basis for determining unfairness altogether. 
Chart 1. Summary of Evolution of the Unfairness Doctrine

\begin{tabular}{|c|c|c|}
\hline Milestones & Event & Interpretation of Unfairness \\
\hline 1938 & $\begin{array}{l}\text { FTC Act amended to extend protection to } \\
\text { consumers }\end{array}$ & No need to prove injury to competition or competitors \\
\hline $\begin{array}{l}1964 \text { Cigarette } \\
\text { Rule }\end{array}$ & $\begin{array}{l}\text { FTC's rule governing the advertising and } \\
\text { sale of cigarettes }\end{array}$ & $\begin{array}{l}\text { 1. Whether the practice offends public policy - as set } \\
\text { forth in statutes, the common law, or otherwise; and } \\
\text { 2. Whether it is immoral, unethical, oppressive, or } \\
\text { unscrupulous; and } \\
\text { 3. Whether it causes substantial injury to consumers (or } \\
\text { competitors or other businessmen). }\end{array}$ \\
\hline 1972 & $\begin{array}{l}\text { The Supreme Court in Sperry suggested that } \\
\text { the 3-prong test can be used disjunctively. }\end{array}$ & $\begin{array}{l}\text { The 3-prong test can be applied disjunctively: } \\
\text { 1. Whether the practice offends public policy; or } \\
\text { 2. Whether they were immoral, etcetera, or } \\
\text { 3. Whether they caused substantial injury to consumers. }\end{array}$ \\
\hline 1978 & $\begin{array}{l}\text { FTC proposed a rule to ban advertising } \\
\text { directed to children based on the grounds } \\
\text { that it was "immoral, unscrupulous, and } \\
\text { unethical" and against generalized public } \\
\text { policies to protect children }\end{array}$ & $\begin{array}{l}\text { The 3-prong test can be applied disjunctively: } \\
\text { 1. Whether The Practice Offends Public Policy; Or } \\
\text { 2. Whether They Were Immoral, Etcetera, or } \\
\text { 3. Whether they caused substantial injury to consumers. }\end{array}$ \\
\hline 1980 & $\begin{array}{l}\text { Congress threatened to restrict the FTC's } \\
\text { authority, including legislation preventing the } \\
\text { FTC from using unfairness in new } \\
\text { rulemakings to restrict advertising. } \\
\text { The FTC issued it Unfairness Policy } \\
\text { Statement }\end{array}$ & $\begin{array}{l}\text { The } 3 \text { prong test changed to: whether } \\
\text { 1. The injury was substantial; and } \\
\text { 2. The injury is not be outweighed by any } \\
\text { countervailing benefits to consumers or } \\
\text { competition that the practice produces; and } \\
\text { 3. The injury is one that consumers themselves could } \\
\text { not reasonably have avoided. }\end{array}$ \\
\hline 1994 & $\begin{array}{l}15 \text { U.S.C. } \S 45(n) \text { was amended to allow } \\
\text { public policy considerations }\end{array}$ & $\begin{array}{l}\text { The FTC may consider established public policies as } \\
\text { evidence but that may not serve as a primary basis for } \\
\text { such determinations. }\end{array}$ \\
\hline
\end{tabular}

The present codification of the unfairness criteria that focuses on the substantial injury to consumer along with a balancing test of benefits to harm was criticized for not giving guidance on exactly what conduct is unfair. The wide range of facts potentially relevant under this criteria are likely to increase the complexity and cost of establishing unfairness. (Belt, 2010). This requires that each situation must be weighed accordingly, thus making it almost impossible to have a concrete example of conduct that are unfair under the law. (Belt, 2010) 
Chart 2. Sec 5 FTC Unfairness Doctrine and Psychological Advertising

\begin{tabular}{|c|c|c|c|}
\hline $\begin{array}{c}\text { Elements / Standard } \\
\text { Definition / Rubric for } \\
\text { Analysis }\end{array}$ & $\begin{array}{c}\text { Challenges Under Current } \\
\text { Law }\end{array}$ & $\begin{array}{c}\text { Examples or Types of } \\
\text { Advertising That Can } \\
\text { Evade the Law }\end{array}$ & $\begin{array}{c}\text { Implications on Consumer } \\
\text { Rights }\end{array}$ \\
\hline $\begin{array}{l}\text { Cause or [are] likely to cause } \\
\text { substantial injury to } \\
\text { consumers }\end{array}$ & $\begin{array}{l}\text { burden of proof is on } \\
\text { consumer to show injury } \\
\text { related to advertising }\end{array}$ & $\begin{array}{l}\text { Psychological ads that } \\
\text { causes impulse buying can } \\
\text { be justified by other } \\
\text { consumers appreciating the } \\
\text { ad for making the product } \\
\text { known to them. }\end{array}$ & $\begin{array}{l}\text { Right to safety is } \\
\text { compromised if injury is } \\
\text { deemed not substantial }\end{array}$ \\
\hline $\begin{array}{l}\text { Which is not reasonably } \\
\text { avoidable by consumers } \\
\text { themselves and }\end{array}$ & $\begin{array}{l}\text { burden of proof is on } \\
\text { consumer to demonstrate } \\
\text { that advertising cannot be } \\
\text { reasonably avoided }\end{array}$ & $\begin{array}{l}\text { An argument that consumer } \\
\text { can merely switch channels } \\
\text { to avoid TV ads, thus can } \\
\text { reasonably avoid them. }\end{array}$ & $\begin{array}{l}\text { Right to information is } \\
\text { compromised if consumers } \\
\text { did not receive product or } \\
\text { service information but } \\
\text { advertisers (or businesses } \\
\text { can show that the practice } \\
\text { benefited other consumers. }\end{array}$ \\
\hline $\begin{array}{l}\text { Not outweighed by } \\
\text { countervailing benefits to } \\
\text { consumers or to competition }\end{array}$ & $\begin{array}{l}\text { burden of proof is on } \\
\text { consumers to balance the } \\
\text { benefits and harm caused by } \\
\text { the advertising practice. }\end{array}$ & $\begin{array}{l}\text { Ads that hurt senior citizens } \\
\text { and children but is } \\
\text { outweighed by the pleasure it } \\
\text { gives to younger group may } \\
\text { NOT be considered unfair. } \\
\text { Ads with false-dichotomies } \\
\text { where an option is given: Ex: } \\
\text { either buy the product, or be } \\
\text { a socially inept; Ex: } \\
\text { associative advertising which } \\
\text { associates a product with an } \\
\text { experiential feeling, like beer } \\
\text { and party -time. (Persuasion, } \\
\text { Manipulation, and } \\
\text { Responsibility) } \\
\text { Plays on emotions and } \\
\text { insinuate a threat on } \\
\text { consumers about the dangers } \\
\text { of not having the product or } \\
\text { service, e.g., insurance ads } \\
\text { which capitalize on fear of } \\
\text { the unknown; or imply } \\
\text { amazing results, e.g., diet pill } \\
\text { ads; or trigger images of } \\
\text { hope and visions of } \\
\text { happiness, e.g., purchasing a } \\
\text { luxury sports car will } \\
\text { transform one into an image } \\
\text { of youth, or a facial crème } \\
\text { that shows removal of } \\
\text { wrinkles (Persuasion, } \\
\text { Manipulation, and } \\
\text { Responsibility). }\end{array}$ & $\begin{array}{l}\text { Right to choose is } \\
\text { compromised with mental } \\
\text { manipulation depriving } \\
\text { control to make rational } \\
\text { choice. }\end{array}$ \\
\hline
\end{tabular}

The pursuit of regulation on affective and other psychological advertising could face parallel challenges as those attempted by the FTC in 1978 to ban ads directed to children based on the grounds that it was "immoral, unscrupulous, and unethical" and against generalized public policies to protect children." Similarly, psychological advertising of any type, but most particularly affective advertising, must be banned on the same grounds. These practices are clearly immoral, unethical, and outright manipulative. Both hinge on generalized public policies - the first one is to protect 
children and this proposal is to protect consumers. The FTC Staff Report on Television Advertising to Children "addresses the problems created by the large volume of current television advertising being directed to children, many of whom naively accept the messages and cannot perceive the selling purpose of television advertising or otherwise comprehend or evaluate it." (Federal Trade Commission, New York, NY. Bureau of Consumer Protection, 1978). Similarly, over a century of study on psychological advertising shows that consumers are bombarded by large volume of ads in various media whose purpose is to trick the mind with psychologically conditioned messages that deprive them of rationale, objective evaluation in their purchasing decision without their knowledge. Today's high-tech society immerses the consumer with full exposure to these ads beyond their control. This paper proposes a revision on the interpretation of this criteria infra.

\section{RATIONALE AND FRAMEWORK FOR REVISIONS TO SEC 5 FTC UNFAIRNESS DOCTRINE}

This proposal focuses on the most problematic interpretation of the law that enables psychological advertising practices and other immoral, unethical, and similar unjust practices to escape the reach of the law. The primary author believes that Sec 5 FTC as written is not deficient in its breadth covering "unfair and deceptive practices," but rather, lacks depth in upholding the highest deference to consumer rights enumerated by President Kennedy. To support my rationale for change, I provide a closer examination of the 3-prong test burden on consumers that challenge an unfair practice, and examine the mission of the FTC discussed in section 3. Based on these, it is convincing that the current law places more protection for businesses than it does consumers. The tone of the current FTC interpretation of the "unfairness" doctrine patterns that of a "caveat emptor" doctrine, Latin for "let the buyer beware." This doctrine serves to warn buyers that the goods or services are not subject to any warranty by the seller and are sold "as is." It "...often places on buyers the burden to reasonably examine property before purchase and take responsibility for its condition." (Cornell University Law School LLI, 1992). This goes against all notion of consumer protection. Therefore, this proposal will shift the focus of the law back on consumer rights and protection.

The main reason for change is drawn from a close analysis of the 1980 FTC Unfairness Policy Statement that placed substantial legal obstacles to consumers who will try to enforce the law. This policy elaborated the "substantial injury to consumer" criteria while acts that are immoral, unethical, etc., were deleted from its interpretation leaving the door open to such unjust practices. Here, the FTC declared that "[un]justified consumer injury is the primary focus of the FTC Act, and the most important of the three S\&H (aka Cigarette Rule") criteria." (Beales, 2003) On its face, this statement seems to suggest concern and care for consumer welfare in preventing their injury. However, careful analysis shows that this is quite the contrary because the FTC currently requires consumers to meet three tests before an act or practice is deemed unfair: 1.) that the injury be substantial; 2.) that the injury must not be outweighed by any countervailing benefits to consumers or competition that the practice produces; and 3.) that the injury must be one that consumers themselves could not reasonably have avoided. Based on this, the proposed revision expands the meaning of each element of the "unfairness" criteria of the FTC Act that will extend the reach and scope of its coverage without tolerance to unjust practices such as psychological advertising. This change is needed to maximize consumer protection where consumers are most vulnerable. There are other federal laws relating to consumer protection, however, we believe that any changes to the FTC Act will pave the way to similar changes in other consumer related laws. We contend that any form of psychological advertising violates consumer's right to information and right to choose supra and will meet the unfair and/or deceptive standard of the Act IF interpreted in the best light for consumers.

The following proposal substantially mirrors much of the concept of the 1978 FTC interpretation suggested by the Supreme Court in Sperry in 1972 that the 3-prong test of the Cigarette Rule can be applied disjunctively, with a more radical twist:

First, the test that the injury be "substantial" must be removed as injury of any magnitude is harm which violates consumer rights. Therefore, a proposal is to treat consumer injury as a per se violation. Here, the FTC Act must merely require a showing of injury that was proximately caused by the unfair practice. Substantiality is not a factor. The only defense would be that the practice did not proximately cause the injury, or that there is no injury. Further, the standard of proof should keep the public policy considerations, clearly defining the position of consumer right as its highest priority as among the possible conflicting public policies (e.g., right to safety vis-a-vis gun policy, commercial speech, etc.). 
Second, the test that the injury must not be outweighed by any "countervailing benefits" to consumers or competition that the practice produces is the most troublesome area of this doctrine and must be removed. This "countervailing benefits" test tilts the law heavily on business protection rather than consumer protection. The FTC notes that it will not find that a practice unfairly injures consumers unless it is injurious in its net effects" (Belt, 2010). This "net effect" is the outcome of the "countervailing benefits" test. This means a balancing test of harm and benefits such that if the net effect is more benefits than harm, then the practice is not unfair. Note that benefits can be drawn from any sector of the consumer or competitor group. For example, sugar ads harm children (health), but if the majority of society benefits from the practice (young adults and seniors enjoy the product), extrapolating a positive net effect on benefits from any sector, then the practice could be deemed legitimate. Here, consumers who were harmed (no matter how substantial) suffer and pay the cost to other consumers who are benefitted. Consumers have no recourse but to continually be subjected to the harmful practice (as we now see with ads directed to children and psychological advertising). This test is such a heavy burden the on the plaintiff consumer due to the complexity and scope of factors that can be considered in weighing the countervailing benefits. Big businesses engaged in the practice could be better equipped to handle the expense and sophistication of such proof. This shows that businesses are protected at the expense of consumers. The business practice will be justified no matter how immoral, unscrupulous, unethical and oppressive it may be. This likewise explains the FTC statement that "[un]justified consumer injury is the primary focus of the FTC Act" meaning that there are consumer injuries that are "justified" as discussed above. This is a blatant violation of consumer rights, at least the right to safety, or any other rights depending on how the consumer is harmed. The 3 tests interpreted in the eyes of the plaintiff affirm that a practice that causes injury will NOT be unfair if the injury is NOT substantial or that the practice also benefits other consumers equally or more, or if the plaintiff could have reasonably avoided the injury. This is confusing, if not obvious, as to which party the law is protecting as it gives a wide latitude of defenses for businesses while placing a heavy 3-prong burden of proof on consumers who challenged the practices. Whereas defendants (mostly businesses) can bypass the law by choosing only one of the many defenses - either prepare an affirmative defense showing a study demonstrating that the benefits of their practice is more than the injuries of the plaintiff ("countervailing benefits" test), or a study showing that the practice can be reasonably avoided by consumers. Consumers have legal rights that should not have to be defended over and over again every time these rights are violated. Balancing their harm with benefits requires a constant fight for these rights. This concept follows the utilitarian view of weighing benefits and harm. This policy ignores the unjust nature of utilitarianism wherein "....it incorrectly overlooks considerations of justice and the distribution of happiness... and concerns itself with the sum total of happiness produced, not with how that happiness is distributed." (Shaw, 2011) Utilitarian view focuses on the results of the action, not on the character of the action itself. (Shaw, 2011). For example, based on a utilitarian concept, killing another is right if the benefit of the killing outweighs the harm, thus justifying wars and death penalties. The permission to weigh some kind of benefits to justify the bad acts blatantly condones bad acts. This explains why the 1980 Unfairness Policy Statement deleted the criteria of acts or practices that are "immoral, unethical, oppressive, or unscrupulous" - because now, these bad acts are acceptable if justified by countervailing benefits (or if the consumer can reasonably avoid them).

Third, the requirement asking consumers to avoid an unfair practice when reasonable (perhaps like changing TV channel if there is deceptive claim in an ad) must be removed as this is asking consumers to constantly and affirmatively act in order to preserve their right against such unfair practices. Since consumer right is a legal right and not a license or privilege, consumers must not have to be burdened to act affirmatively to receive those rights. An example of this affirmative act is when consumers are asked to "opt out" whenever businesses deliver junk mail or post pop up ads in our private space without permission thus intruding on privacy. Here, consumers have the right not to be harmed by these practices. Asking them to avoid it when reasonable imposes an affirmative action to preserve their right. Consumer rights trump licensees. Businesses are temporary licensees to operate - they do not have the right to do so. Business licensing requires that the business must serve the public good. This is the party that has to constantly change their behavior if these are stepping on consumer's right. Political and corporate pressure has twisted these roles and confused society as to who has a right that is inalienable and fixed, and who has a mere license that is limited and temporary such that laws governing the inalienable rights are asked to adapt and subscribe to the temporary license holders by virtue of power control. An example is the "consumer beware" syndrome. This is another proof that these laws support businesses more than the consumers. 
Fourth, the public policy element of the Cigarette Rule must be re-adopted as one type of unfair practice: "whether the practice offends public policy - as set forth in statutes, the common law, or otherwise-whether, in other words, it is in at least the penumbra of some common law, statutory, or other established concept of unfairness. the current legal interpretation of unfairness serves as an avenue of defense to support practices that goes against public policies, including consumer rights. The FTC Act and 15 U.S.C. $\S 45(\mathrm{n})$ treats the role of public policy as mere evidence to be considered in determining the balance of costs and benefits and not a goal by itself. This means that an act or practice that goes against public policies may still be legal as against consumers upon showing of benefits or consumer availability.

Lastly, practices that are immoral, unethical, oppressive, or unscrupulous are clearly unfair and must be re-adapted. This element need not have to be argued as these acts are codify standards of decency in and of themselves.

Below reflects the above proposal which is a modified re-adaption of Cigarette Rule on unfairness:

An act or practice is unfair to consumers: (1) if the practice, without necessarily having been previously considered unlawful, offends public policy as it has been established by statute, the common law, or otherwise-whether, in other words, it is in at least the penumbra of some common law, statutory, or other established concept of unfairness; or (2) if it is immoral, unethical, oppressive, or unscrupulous; or (3) if it causes injury to consumers, competitors, or other businessmen.

The theme of this change is to support a consumer-centric economy which requires a shifting of paradigm from "consumer beware" to "consumer respect." This will require a shift in consciousness which alerts businesses to more mindful of their practices, rather than asking consumers to be always on alert business practices. Further, we deduce an assumption for further research that competition can be driven heavily by the advertisers with heavier funding rather than competition driven by product superiority or differentiation.

\section{AUTHOR BIOGRAPHIES}

Michelle Alarcon (contact author) is a licensed attorney in Hawaii, USA and an associate professor at Hawaii Pacific University. She earned her J.D. at Loyola Law School, Los Angeles, CA and an MBA from Pepperdine University, Los Angeles, CA. Her primary teaching area are Business Law and Management. Email: malarcon@hpu.edu

Joseph Ha earned his Ph.D. at Rutgers University. He is a professor at Hawaii Pacific University. His primary teaching is Marketing. He currently serves as program chair of Marketing at the College of Business Administration. Email: jha@hpu.edu

\section{REFERENCES}

15 U.S.C. $\S \S 41-58$, as amended. (n.d.).

15 U.S.C. Sec. 45(a)(1). (n.d.).

Beales, J. H. (2003, May 30). The FTC's Use of Unfairness Authority: Its Rise, Fall, and Resurrection. Retrieved from Federal Trade Commission: Protecting America's Consumers: http://www.ftc.gov/public-statements/2003/05/ftcs-useunfairness-authority-its-rise-fall-and-resurrection

Beauchamp, T. (1983). Manipulative Advertising. Business and Professional Ethics Journal , 5.

Belt, D. L. (2010, Feb). ShouldThe FTC's Current Criteria for Determining “Unfair Acts or Practices”Be Applied to State "Little FTC Acts"? Retrieved from theantitrustsource: http://www.americanbar.org/content/dam/aba/publishing/antitrust_source/Feb10_Belt2_25f.authcheckdam.pdf

Bulbul, C. A. (2010, June). The Power of Emotional Appeals in Advertising. Journal of Advertising Research.

Carter, C. (2009). A 50-State Report on Unfair and Deceptive Acts and Practices Statutes. National Consumer Law Center Inc.

Chang, H. H., Pham, M.T. (2012, November). Affect as a Decision-Making System. Journal Of Consumer Research, 40, 42.

Cornell University Law School LLI. (1992). Legal Information Institute. Retrieved from Caveat Emptor: http://www.law.cornell.edu/wex/caveat_emptor

FDIC Compliance Manual Vol. VII. (2014, January). Federal Trade Commission.

Federal Trade Commission. (2008, Julu). A Brief Overview of the Federal Trade Commission's Investigative and Law Enforcement Authority. Retrieved from Federal Trade Commission Protecting America's Consumers: http://www.ftc.gov/about-ftc/what-we-do/enforcement-authority 
Federal Trade Commission, New York, NY. Bureau of Consumer Protection. (1978, Feb). ERIC - FTC Staff Report on Television Advertising to Children. Retrieved from ERIC Collection: http://eric.ed.gov/?id=ED178083

Federal Trade Comm'n v. Verity Int'l Ltd., 443 F.3d 48 (2d Cir. 2006).

FTC Policy Statement on Deception. (1983, October 14). Retrieved from Federal Trade Commission Protecting America's Consumers: http://www.ftc.gov/ftc-policy-statement-on-deception

FTC.gov. (n.d.). Retrieved 05 04, 2014, from Federal Trade Commission: Protecting America's Consumers: http://www.ftc.gov/about-ftc

Heath, R. (2001). The Hidden Power of Advertising. Admap Publications.

Heath, R. (2012). Seducing the Subconscious: The Psychology of Emotional Influence in Advertising. John Wiley \& Sons.

Ingram, D. (n.d.). Alternatives to Manipulative Advertisements. Retrieved from AZ Central: http://yourbusiness.azcentral.com/alternatives-manipulative-advertisements-23199.html

Lampman, R. J. (1997). The Consumer Bill of Rights thirty-five years later. Advancing the Consumer Interest(2), 4. Retrieved from http://www.consumerinterests.org/i4a/pages/index.cfm?pageid=3312

Lawrence, A. T. (2014). Consumer Protection. In A. T. Lawrence, Business and Society: Stakeholders, Ethics, Public Policy (p. 333). New York: McGraw-Hill Irwin.

Medical Dictionary. (n.d.). Retrieved from The Free Dictionary: http://medicaldictionary.thefreedictionary.com/Psychological+conditioning

Nickels, W. G. (2013). Understanding Business. New York: McGraw-Hill Irwin.

Persuasion, Manipulation, and Responsibility. (n.d.). Retrieved from Learning Ace: https://people.creighton.edu/ agu10010/articles/Persuasion\%20\&\%20Manipulation\%20JPBE.doc

Psychological Tactics and Appeals in Advertising. (n.d.). Retrieved 2014, from Psychology and Advertising: http://www.angelfire.com/va3/psychmethods/PSYCH.html

Schwab v. Philip Morris USA, Inc., 449 F.Supp.2d 992 (E.D.N.Y 2006).

Scott, W. D. (1902). The Psychology of Advertising. Retrieved 05 2014, from Internet Archive: http://archive.org/stream/advertpshycho00scotrich/advertpshycho00scotrich_djvu.txt

Shaw, W. H. (2011). Normative Theories of Ethics. In W. H. Shaw, Business Ethics (pp. 57-58). Boston: Wadsworth Cengage Learning.

Studlar, D. (2002). Tobacco Control: Comparative Politics in the United States and Canada . 55.

Sulzberger, A. J. (1981, April 3). F.T.C. staff urges end to child-tv ad study. Retrieved from New York Times Business Day: http://www.nytimes.com/1981/04/03/business/ftc-staff-urges-end-to-child-tv-ad-study.html

Taute, H.A., McQuitty, S., \& Sautter, E.P. (2011) Emotional Information Management and Responses to Emotional Appeals, Journal of Advertising, 40:3, 31-44, DOI: 10.2753/JOA0091-3367400303

Todd. (2011, June 20). BuySellAds. Retrieved from The Sneaky Psychology Of Advertising: http://blog.buysellads.com/2011/thesneaky-psychology-of-advertising/

Torabi, F. (2011, May 2). Pricing Psychology: 7 Sneaky Retail Tricks. Retrieved from CBS Money Watch: http://www.cbsnews.com/news/pricing-psychology-7-sneaky-retail-tricks/

Trampe, D. D. (2010, October 14). The Self-Activation Effect of Advertisements: Ads Can Affect Whether and How Consumers Think about the Self. Journal of Consumer Research, 1030-1045. 


\section{APPENDIX 1}

Data on How Psychology in Advertising Influences Consumer Behavior and Decision Making

A. But the future must needs be full of better methods than these to make advertising advance with the same rapidity as it has during the latter part of the last century. And this will come through a closer knowledge of the psychological composition of the mind. The so-called "students of human nature" will then be called successful psychologists, and the successful advertisers will be likewise termed psychological advertisers." Further, "[s]cientific advertising follows the laws of psychology. The successful advertiser, either personally or through his advertising department, must carefully study psychology. He must understand how the human mind acts. He must know what repels and what attracts. He must know what will create an interest and what will fall flat. He must be a student of human will fall flat. He must be a student of human MIND. (Scott, 1902)

B. As their entire object is to produce certain effects on the minds of possible customers, it is not strange that they have turned to psychology in search of such principles.... [f]or, however diverse their occupations may at first sight appear, the advertisement writer and the teacher have one great object in common - to influence the human mind.... [a]s their entire object is to produce certain effects on the minds of possible customers, it is not strange that they have turned to psychology in search of such principles... [t]he method employed by the psychologist in attempting to give advertising a theoretical basis has been quite uniform. He has first analyzed the human mind into its various activities, then analyzed advertisements to discover what there is in them that may or may not awaken the activity desired... (people) are unconscious of the fact that the results secured are the ones sought for, and that in planning the advertising campaign the merchant has made a study of the minds of these same householders, mechanics, business men, and members of the family. (Scott, 1902)

C. 'Free' Stuff - still requires us to spend money but are marketing gimmicks businesses bank on, knowing that consumers simply can't resist., 2. Bye, Bye, Dollar Signs- e.g., "[e]xpensive restaurants usually have minimalistic prices like "24" -- meaning $\$ 24.00$-- because they want you to focus on the food and not the price", 3. ' 10 for $\$ 10^{\prime}$ - "[y]ou may see this at supermarkets: "10 boxes of cereal for $\$ 10$." Consumers often think they have to buy 10 items to get the deal - but sometimes it's just another way of advertising 1 for $\$ 1$. "You don't have to buy 10 to get the price, but some people do - or at any rate, they buy more than they would have, convinced that they're getting some kind of great deal, says Poundstone.", 4. PerCustomer Limits - You may also see this type of pricing at the supermarket: "Limit 5 per customer." This leads people to think 'Oh, this is scarce, I should buy this," 5. The 9 Factor - "Prices ending in 9, 99, or 95 are called 'charm prices, 6 . Easy Math-Some stores will put a product on sale and show you what price it was marked down from. If the difference is easy to calculate, we tend to think it's a better and bigger deal (Torabi, 2011).

D. Emotional appeals and advertising can be distinguished by their valence as positive (e.g., warmth, friendship, or love as a reward for compliance) or negative (e.g., guilt, shame, or fear for noncompliance). Both positively and negatively valenced messages are thought to strengthen responses to advertising, but there is substantial disagreement regarding the factors that affect responses to emotional advertising, and these factors may differ across positively and negatively valenced ads (Taute, 2011 citing Homer and Yoon 1992 and Moore and Harris 1996). Explanations of the effects of positively valenced ads, however, typically rely on classical conditioning, other behaviorist theories (e.g., excitation transfer), and information-processing models (e.g., elaboration likelihood) (Taute, 2011 citing Edell \& Burke, 1987; Gorn, 1982; Machleit \& Wilson, 1988; Petty \& Cacioppo, 1983; Ray \& Batra, 1983; Shiv, Edell, \& Payne 1997). ...finding supports conceptualizations of emotional competencies that include empathy as a determinant of attitudes and behaviors (Taute, 2011 citing Goleman, 1998 and Tapia, 2001).

E. Bulbul, (2010) helps extend our thinking on the role of emotional appeals in advertising as they introduce a new distinction in such appeals: "concrete versus abstract affect" showing that concrete affective appeals drive behavioral intentions more strongly in the short-term perspective, whereas abstract affective appeals appear to drive behavioral intentions more strongly in the longer-term perspective proposes that concrete affect could thus impair self-control and influence immediate decisions more than distant ones. (Bulbul, 2010)

F. "Consumer judgments and decisions can be made either in a largely cognitive, reason-based manner- 
by assessing, weighing, and combining attribute information into an overall evaluative judgment - or in a largely affective, feeling-based manner, by inspecting one's momentary feelings toward the options" (Chang, 2012) quoting Pham 1998 and citing Schwarz \& Clore, 2007).

Emotional manipulation occurs when advertisers intentionally stir up an emotion, such as joy or fear, to encourage impulse purchases. Psychological manipulation occurs when advertisers take advantage of viewers' self-image, worries, addictions, misinformed beliefs or other mental factors. (Ingram, n.d.)

G. For over 70 years the universal assumption has been that advertising is only effective if it consciously persuades consumers to choose a particular brand. In such circumstances attention is critical, which is why most of the advertising industry's creative resource is focused on achieving the highest possible levels of interest and awareness. But how is it that advertising can and frequently does work, even when consumers have no conscious awareness of having seen or heard the ads themselves? (Heath, The Hidden Power of Advertising, 2001).

H. Recent neuroscientific research has shown that the brain's capacity to absorb certain types of brand information is far greater than we ever imagined. Building on these findings, Robert Heath is able to explain with exceptional clarity how advertising creates meaningful and enduring brand associations in our minds, even when we pay virtually no attention to it. These associations exert a powerful influence on our intuitive feelings, and can unknowingly drive us to choose and buy particular brands. (Heath, The Hidden Power of Advertising, 2001).

I. This mechanism - low involvement processing - turns out to be an especially effective way of getting through to consumers, who in general have little or no interest in learning about brands. Heath shows that low involvement processing has been a major factor behind the success of mega-brands in markets as diverse as insurance, cars, toilet paper, cigarettes, and beer. (Heath, The Hidden Power of Advertising, 2001).

Robert Heath's 2012 book "Seducing the Subconscious" is supported by current research where he uses experimental psychology and cognitive neuroscience to outline his theory of the subconscious influence of advertising on consumers. He wrote that advertising has ways of influencing us in ways we don't know of and that don't involve persuasion. (Heath, Seducing the Subconscious: The Psychology of Emotional Influence in Advertising, 2012): Summary.

J. In 1990's, researchers began measuring EEG (Electroencephalography) activity to learn about attention in consumers. Print ads are left hemisphere dominant, Video ads are right hemisphere dominant. Brain activity is higher during new commercials than during older ones, and they have more impact on a person's memory and cognition. The more extravagant an ad claim is, the larger the sales. Advertisers use color to associate products with moods and feelings of the consumer. (Psychological Tactics and Appeals in Advertising, n.d.). 


\section{APPENDIX 2}

Excerpt from Summary of 50-State Report on Unfair and Deceptive Acts and Practices Statutes (Carter, 2009).

The holes are glaring. Legislation or court decisions in dozens of states have narrowed the scope of UDAP laws or granted sweeping exemptions to entire industries. Other states have placed substantial legal obstacles in the path of officials charged with UDAP enforcement, or imposed ceilings as low as $\$ 1,000$ on civil penalties. And several states have stacked the financial deck against consumers who go to court to enforce the law themselves. Specific findings include:

- UDAP protections in Michigan and Rhode Island have been gutted by court decisions that interpret the statute as being applicable to almost no consumer transactions.

- Iowa does not allow consumers who have been cheated to go to court to enforce UDAP provisions.

- In addition to Michigan and Rhode Island, three states - Louisiana, New Hampshire, and

- Virginia - exempt most lenders and creditors from UDAP statutes, while another 15 leave significant gaps or ambiguities in their coverage of creditors.

- Utility companies in 16 states enjoy immunity from UDAP laws, as do insurance companies in 24 states.

- Five states - Colorado, Indiana, Nevada, North Dakota, and Wyoming - impede the Attorney General's ability to stop ongoing unfair or deceptive practices by conditioning an injunction or any other relief upon proof that those practices were done knowingly or intentionally.

- While all states except Iowa allow consumers to go to court to enforce UDAP laws, five states - Arizona, Delaware, Mississippi, South Dakota, and Wyoming - impose a financial burden on those consumers by denying them the ability to recover their attorney's fees.

- Worse, in Florida and Oregon, courts have required unsuccessful consumers to pay tens of thousands of dollars to the business for its attorney fees, even though the consumers filed suit in good faith. Alaska's UDAP statute requires unsuccessful consumers to pay partial attorney fees to the business, and in three other states the UDAP statute has not yet been authoritatively interpreted to rule out this result.

- A number of states impose special procedural obstacles on consumers that can hinder or even prevent them from enforcing the UDAP statute. 
NOTES 